\title{
ANALISIS TINGKAT KEUNTUNGAN PETANI KENTANG MERAH DI KABUPATEN SOLOK
}

\author{
Dian Fauzi \\ Dosen Program Studi Agribisnis, Universitas Tamansiswa Padang \\ dhi_fauzi20@yahoo.co.id
}

\begin{abstract}
Abstrak
Tujuan dari penelitian ini adalah untuk menganalisa pendapatan dan keuntungan petani kentang merah di Kabupaten Solok Provinsi Sumatera Barat. Penelitian ini berlokasi di Kecamatan Lembah Gumanti. Metode penelitian yang digunakan adalah analisis usahatani. Berdasarkan hasil analisis usahatani diperoleh rata-rata tingkat keuntungan petani kentang merah di Kabupaten Solok sebesar Rp 1.521,83/kg dengan R/C Ratio atas biaya total 1,25.
\end{abstract}

Kata Kunci : agribisnis, kentang merah, usahatani

\section{PENDAHULUAN}

Kentang merah merupakan komoditas hortikultura yang berpeluang untuk dikembangkan di bidang agribisnis dan agroindustri. Hal ini disebabkan oleh harga kentang merah yang relatif stabil, potensi bisnisnya tinggi, segmen usaha dapat dipilih sesuai dengan modal, pasar terjamin dan pasti. Dari segi perlakuan pascapanen, kentang merahmemiliki sifat daya simpan lebih lama dibanding jenis tanaman sayur lain seperti kubis, bawang merah, dan buncis.

Kabupaten Solok merupakan suatu kawasan pegunungan yang terletak di Provinsi Sumatera Barat dengan ketinggian rata-rata $1.458 \mathrm{~m}$ dpl. Salah satu komoditas hortikultura yang dikembangkan di wilayah Kabupaten Solok adalah kentang merah. Kentang merah mulai dibudidayakan di Kabupaten Solok semenjak tahun 2012. Alasan pemerintah menggiatkan budidaya kentang merah ke petani karenakentang merah akan dijadikan komoditi unggulan daerah dengan dukungan lahan Kabupaten Solok yang cocok untuk ditanami kentang merah serta Kabupaten Solok merupakan satu-satunya daerah di Sumatera Barat yang membudidayakan kentang merah.Alasan lainnya yakni petani menyukai budidaya kentang merah karena pemeliharaan yang sederhana dan tahan terhadap serangan hama.

Kentang merah memiliki kulit buah yang berwarna merah, namun daging buahnnya berwarna kuning. Kandungan karbohidrat yang terdapat didalam kentang merah lebih banyak, sedangkan kadar airnya lebih rendah. Hal ini membuat olahan kentang menjadi keripik atau makanan lain akan lebih renyah dan lezat.Samadi (2002) mengatakan bahwa dalam setiap 100 gram kentang merah mengandung 85.6 gram karbohidrat, 347 kalori,20 mg kalsium, 0.3 gram protein, $30 \mathrm{mg}$ fosfor, 0.1 gram lemak, $0,5 \mathrm{mg}$ zat besi, dan 0,04 $\mathrm{mg}$ vitamin B. Kentang merah dapat dikonsumsi dalam berbagai macam bentuk olahan,misalnya dikonsumsi dalam bentuk rebusan, gorengan, aneka snack, perkedel, dan berbagai bentuk makanan olahan lainnya.

Berdasarkan hasil wawancara dengan kepala Unit Pelaksana Teknis Daerah Kabupaten Solok, produksi rata-rata kentang merah di Solok sebesar 15 ton/ ha. Namun, hal ini belum didukung oleh distribusi pemasaran yang baik.Selama ini petani menjual hasil panennya ke tengkulak dengan harga jual yang relatif rendah, yakni berkisar Rp 
5.500/ kg. Sedangkan di tingkat konsumen harga kentang merah mencapai Rp 12.000/kg hingga Rp 13.000/kg.

Kendala lain yang dihadapi petani adalah belum optimalnya pengendalian sumber daya alam, masih rendahnya pengetahuan petani terhadap budidaya kentang merah, sulitnya mendapatkan bibit, harga bibit yang cenderung lebih mahal dibanding dengan harga bibit kentang biasa. Pada umumnya petani memperoleh bibit kentang merah dari sisa panen yang kemudian mereka jadikanuntuk penanaman selanjutnya. Dari permasalahn yang ada maka tujuan dari penelitian ini adalah untuk menganalisa pendapatan dan keuntungan petani kentang merah di Kabupaten Solok Provinsi Sumatera Barat.

\section{METODE PENELITIAN}

\section{Analisis Usahatani}

Menurut Soekartawi (1995) analisis unit usaha yang sederhana dapat dilakukan dengan menggunakan formula Total Cost (TC), Total Revenue (TR) dan Keuntungan $(\pi)$.

a) Total cost adalah keseluruhan biaya yang dikeluarkan dalam menghasilkan output.

$$
\text { Total Cost }(\mathrm{TC})=\mathrm{FC}+\mathrm{VC}
$$

Total Fixed Cost (TFC): biaya yang dikeluarkan oleh petani yang tidak mempengaruhi hasil output/ produksi. Contoh: pajak, , iuran irigasi sewa tanah, alat pertanian.

Total Variable Cost (TVC) yaitu biaya yang besarnya berubah searah dengan berubahnya jumlah output yang dihasilkan.

b) Total Revenue adalah jumlah penerimaan total suatu perusahaan yang diperoleh dari besarnya tingkat produksi dikalikan dengan tingkat harga.

Secara matematis dirumuskan sebagai berikut:

$$
\mathrm{TR}=\mathrm{P} X \mathrm{Q}
$$

Keterangan:

$T R=$ Total Revenue (Total Penerimaan)

$P \quad=$ Price (Harga)

$Q \quad=$ Quantity (Jumlah)

c) Keuntungan Usahatani adalah selisih antara penerimaan dan semua biaya.

$$
\text { Keuntungan }=\text { TR }(\text { Total Revenue }) \text { - TC }
$$

Analisis $\mathrm{R} / \mathrm{C}$ rasio merupakan alat analisis dalam usahatani yang berfungsi untuk mengukur efisiensi dari kegiatan usahatani yang dilaksanakan dengan membandingkan nilai output terhadap nilai inputnya atau dengan kata lain membandingkan penerimaan usahatani dengan pengeluaran usahataninya. Adapun rumus $\mathrm{R} / \mathrm{C}$ rasio atas biaya tunai menurut Soekartawi (1995) adalah sebagai berikut:

$$
\frac{R}{C} \text { atas biaya tunai }=\frac{\text { penerimaan tunai }}{\text { biaya tunai }}
$$

Sedangkan $\mathrm{R} / \mathrm{C}$ rasio atas biasa total adalah sebagai berikut :

$$
\frac{R}{C} \text { atas biaya total }=\frac{\text { total penerimaan }}{\text { total biaya }}
$$


Analisis $\mathrm{R} / \mathrm{C}$ rasio dilakukan untuk mengetahui besarnya penerimaan yang dihasilkan dari setiap rupiah yang dikeluarkan pada suatu kegiatan usahatani. Jika rasio R/C bernilai lebih dari satu $(\mathrm{R} / \mathrm{C}>1)$, maka usahatani layak untuk dilaksanakan. Sebaliknya jika rasio $\mathrm{R} / \mathrm{C}$ bernilai kurang dari satu $(\mathrm{R} / \mathrm{C}<1)$, maka usahatani tersebut tidak layak untuk dilaksanakan. Namun, apabila rasio $\mathrm{R} / \mathrm{C}$ sama dengan satu $(\mathrm{R} / \mathrm{C}=1)$, maka usahatani tersebut impas, tidak memberikan keuntungan maupun kerugian.

Tabel 1 Ringkasan perhitungan analisa usahatani

\begin{tabular}{|c|c|c|}
\hline No & Uraian & Perhitungan \\
\hline A & Penerimaan tunai & Harga $\mathrm{x}$ hasil panen yang dijual $(\mathrm{kg})$ \\
\hline $\mathrm{B}$ & $\begin{array}{l}\text { Penerimaan yang } \\
\text { diperhitungkan }\end{array}$ & $\begin{array}{l}\text { Harga } \mathrm{x} \text { hasil panen yang dikonsumsi atau } \\
\text { dijadikan bibit }(\mathrm{kg})\end{array}$ \\
\hline $\mathrm{C}$ & Total Penerimaan & $A+B$ \\
\hline $\mathrm{D}$ & Biaya Tunai & $\begin{array}{l}\text { a. Biaya sarana produksi : } \\
\text { Bibit, pupuk kandang, pupuk kimia, obat- } \\
\text { obatan } \\
\text { b. Biaya Tenaga Kerja Luar Keluarga (TKLK) } \\
\text { c. Pajak } \\
\text { d. Sewa lahan }\end{array}$ \\
\hline $\mathrm{E}$ & Biaya Diperhitungkan & $\begin{array}{l}\text { a. Bibit } \\
\text { b. Biaya Tenaga Kerja Dalam Keluarga } \\
\text { (TKDK) } \\
\text { c. Lahan milik sendiri } \\
\text { d. Penyusutan peralatan }\end{array}$ \\
\hline $\mathrm{F}$ & Total biaya & $\mathrm{D}+\mathrm{E}$ \\
\hline $\mathrm{G}$ & $\begin{array}{l}\text { Pendapatan atas biaya } \\
\text { tunai }\end{array}$ & $A-D$ \\
\hline $\mathrm{H}$ & $\begin{array}{l}\text { Pendapatan atas biaya } \\
\text { total }\end{array}$ & $\mathrm{C}-\mathrm{F}$ \\
\hline I & $\mathrm{R} / \mathrm{C}$ atas biaya tunai & $\mathrm{A} / \mathrm{D}$ \\
\hline $\mathrm{J}$ & $\mathrm{R} / \mathrm{C}$ atas biaya total & $\mathrm{C} / \mathrm{F}$ \\
\hline
\end{tabular}

Sumber : Suratiyah, 2006 (diolah)

Biaya penyusutan alat-alat pertanian diperhitungkan dengan membagi selisih antara nilai pembelian dengan nilai sisa yang ditafsirkan dengan lamanya modal pakai dan disumsikan tidak laku apabila dijual. Metode yang digunakan adalah metode garis lurus (straight line method). Metode garis lurus menggunakan dasar pemikiran bahwa benda yang dipergunakan dalam usahatani menyusut dalam besaran yang sama setiap tahunnya. Secara matematis penyusutan tersebut dirumuskan menurut Suratiyah (2006) sebagai berikut:

$$
\text { Penyusutan per tahun }=\frac{\text { Cost }- \text { Nilai Sisa }}{\text { umur ekonomis }}
$$

\section{HASIIL DAN PEMBAHASAN}

Biaya usahatani adalah seluruh biaya yang dikeluarkan oleh petani pada saat melakukan usahatani kentang merah. Berdasarkan teknis budidaya usahatani kentang merah, biaya usahatani ini terdiri dari biaya yang dibayarkan dan biaya yang diperhitungkan. 
a. Biaya Dibayarkan

Biaya yang dibayarkan meliputi biaya bibit, biaya pestisida, biaya pembelian pupuk kandang, pupuk buatan, biaya Tenaga Kerja Luar Keluarga (TKLK) dan Pajak Bumi dan Bangunan (PBB).

Rata-rata banyaknya penggunaan bibit yang digunakan oleh petani adalah sebesar $800 \mathrm{~kg} / \mathrm{ha} / \mathrm{MT}$. Rata-rata biaya bibit per hektar yang dikeluarkan oleh petani kentang merah di Kabupaten Solok adalah Rp12 000 000,- / ha/ MT. Harga bibit kentang merah di Kabupaten Solok pada saat penelitian adalah Rp15 000,-/kg.

Pada kegiatan pemupukan, jenis pupuk yang biasa digunakan responden untuk budidaya kentang merah cukup beragam. Tidak saja dari jenis pupuk tapi juga dari dosis yang digunakan. Jenis pupuk yang digunakan yaitu pupuk kandang, urea, NPK, SP-36, baron. Dimana biaya yang harus dibayarkan responden untuk pembelian pupuk adalah pupuk kandang seharga Rp400,-/ kg, pupuk urea seharga Rp2 000,-/ kg, pupuk NPK seharga Rp2 300,-/ kg, pupuk SP-36 seharga Rp2 600,-/ kg dan pupuk baron seharga Rp25 $500,-/ \mathrm{kg}$.

Jumlah pupuk yang digunakan petani tergantung dari luas lahan yang dimilikinya dan biaya yang mereka keluarkan tergantung dari banyaknya pemakaian pupuk yang digunakan. Pada Tabel 2 disajikan rata-rata penggunaan pupuk serta biaya yang dikeluarkan oleh petani responden pada usahatani kentang merah.

Tabel 2 Rata-rata per hektar penggunaan pupuk dan biaya pembelian pupuk

\begin{tabular}{lcc}
\hline \multicolumn{1}{c}{ Jenis Pupuk } & Penggunaan $(\mathrm{kg})$ & Biaya $(\mathrm{Rp})$ \\
\hline Kandang & 8000 & 3200000 \\
Urea & 200 & 400000 \\
NPK & 300 & 690000 \\
SP-36 & 200 & 520000 \\
Boron & 300 & 127500 \\
\hline Jumlah & 9327 & 4937500 \\
\hline
\end{tabular}

Sumber : Data primer, diolah

Pada Tabel 2 dapat dilihat bahwa jumlah biaya pembelian pupuk per hektar adalah Rp 4.937.500,-. Biaya ini diperoleh berdasarkan jumlah pupuk yang digunakan oleh petani responden.

Untuk menjaga produktivitas kentang merah agar tetap baik, responden tidak hanya melakukan kegiatan pemupukan, namun mereka juga melakukan kegiatan pengendalian hama dan penyakit dengan penyemprotan pestisida. Jumlah penggunaan pestisida yang digunakan oleh petani tergantung dari luas lahan yang dimilikinya dan biaya yang mereka keluarkan tergantung banyaknya pemakaian pestisida yang digunakan. Pada usahatani kentang merah, petani hanya menggunakan satu jenis pestisida saja, hal ini disebabkan karena tanaman kentang merah tahan terhadap penyakit.

Dari hasil penelitian diperoleh bahwa cara pengendalian hama yang dilakukan petani adalah dengan memotong dan membuang tangkai daun yang tidak produktif sehingga sinar matahari dan pestisida yang disemprotkan bisa masuk mengenai daun yang masih produktif. Rata-rata penggunaan pestisida per yang digunakan petani per hektar adalah 2 botol dan rata-rata biaya yang dikeluarkan per hektarnya adalah Rp 58.000,-. Biaya yang dikeluarkan untuk pembelian pestisida adalah sebesar Rp 29.000,-/ botol $100 \mathrm{ml}$.

Penggunaan mulsa pada usahatani kentang merah juga sangat penting. Mulsa berfungsi sebagai penutup tanaman budidaya untuk menjadi kelembaban tanah serta 
menekan pertumbuhan gulma dan penyakit sehingga tanaman kentang merah tumbuh dengan baik. Rata-rata penggunaan mulsa per hektar pada usahatani kentang merah adalah 2,03 rol dengan rata-rata biaya yang dikeluarkan per hektarnya $\mathrm{Rp} 784.818,27$.

Tenaga kerja merupakan salah satu faktor produksi yang penting dalam usahatani. Besarnya upah untuk tenaga kerja pria adalah $\mathrm{Rp} 40.000,-/$ orang/ hari dan upah tenaga kerja wanita adalah $\mathrm{Rp} 30.000,-/$ orang/ hari. Pada Tabel 3 disajikan distribusi rata-rata penggunaan tenaga kerja luar keluarga pada usahatani kentang merah.

Tabel 3 Distribusi penggunaan tenaga kerja luar keluarga pada usahatani kentang merah musim tanam Agustus-November 2017

\begin{tabular}{llrrrr}
\hline \multirow{2}{*}{ No } & Jenis Kegiatan & \multicolumn{2}{c}{ TKLK } & \multicolumn{2}{c}{ Biaya TKLK } \\
\cline { 3 - 6 } & & $\mathrm{P}$ & $\mathrm{L}$ & $\mathrm{P}$ & \multicolumn{1}{c}{$\mathrm{L}$} \\
& & $(\mathrm{HKP})$ & $(\mathrm{HKP})$ & $(\mathrm{Rp})$ & \multicolumn{1}{c}{$(\mathrm{Rp})$} \\
\hline 1. & Persiapan Lahan & 0 & 404.8 & 0 & 16192 \\
2. & Penanaman & 0 & 4.8 & 0 & 000 \\
3. & Pemupukan & 0 & 1.3 & 0 & 192000 \\
4. & Perlindungan & 0 & 0 & 0 & 52000 \\
5. & Panen & 0 & 124.5 & 0 & 0 \\
& & & & & 4980000 \\
\hline
\end{tabular}

Sumber : Data primer, diolah

Rata-rata biaya yang dikeluarkan untuk penggunaan tenaga kerja luar keluarga adalah Rp 20.667.738,82. Rata-rata penggunaan tenaga kerja luar keluarga per hektar lebih kecil dibandingkan dengan rata-rata penggunaan tenaga kerja dalam keluarga. Jumlah penggunaan tenaga kerja yang digunakan oleh petani tergantung dari luas lahan yang dimilikinya dan biaya yang mereka keluarkan tergantung dari banyaknya pemakaian tenaga kerja yang mereka gunakan.

Pajak Bumi dan Bangunan (PBB) juga termasuk kedalam biaya yang dikeluarkan dalam usahatani kentang merah. Dari hasil penelitian diketahui bahwa PBB yang berlaku di Kabupaten Solok untuk areal usahatani adalah $\mathrm{Rp} 30.000,-/ \mathrm{Ha} / \mathrm{Tahun}$. Rata-rata pajak yang harus dibayar petani responden pada saat penelitian adalah sebesar Rp 10.000,-/ ha/ MT.

b. Biaya Diperhitungkan

Yang termasuk biaya yang diperhitungkan pada usahatani kentang merah adalah biaya Tenaga Kerja Dalam Keluarga (TKDK), biaya penyusutan peralatan, biaya sewa lahan dan biaya bunga modal.

Pada usahatani kentang merah, petani responden umumnya menggunakan tenaga kerja dalam keluarga untuk mengolah usahataninya. Pada Tabel 4 disajikan data tentang distribusi penggunaan tenaga kerja dalam keluarga. 
Tabel 4 Distribusi penggunaan tenaga kerja dalam keluarga pada usahatani kentang merah per hektar musim tanam Agustus-November 2017

\begin{tabular}{llrrrr}
\hline \multirow{2}{*}{ No } & Jenis Kegiatan & \multicolumn{2}{c}{ TKDK } & \multicolumn{2}{c}{ Biaya TKDK } \\
\cline { 3 - 6 } & & $\mathrm{P}$ & $\mathrm{L}$ & \multicolumn{1}{c}{$\mathrm{P}$} & $\mathrm{L}$ \\
& & $(\mathrm{HKP})$ & $(\mathrm{HKP})$ & \multicolumn{1}{c}{$(\mathrm{Rp})$} & \multicolumn{1}{c}{$(\mathrm{Rp})$} \\
\hline 1. & Persiapan Lahan & 38.83 & 141.60 & 1164900 & 5664000 \\
2. & Penanaman & 29.40 & 129.10 & 882000 & 5164000 \\
3. & Pemupukan & 23.00 & 43.20 & 690000 & 1728000 \\
4. & Perlindungan & 51.20 & 64.00 & 1536000 & 2560000 \\
5. & Panen & 17.30 & 36.27 & 519000 & 1450800 \\
\hline
\end{tabular}

Sumber : Data primer, diolah

Rata-rata biaya yang dikeluarkan untuk penggunaan tenaga kerja dalam keluarga adalah Rp 20.610.099,71.

Dari hasil penelitian diperoleh bahwa semua lahan usahatani kentang merah yang dikelola oleh petani responden adalah lahan sendiri. Jadi petani responden tidak mengeluarkan biaya sewa lahan untuk melaksanakan usahatani kentang merah. Namun dalam perhitungan usahatani, biaya sewa lahan tetap diperhitungkan. Biaya sewa lahan di Kabupaten Solok pada saat penelitian adalah sebesar Rp 850.000,-/ ha/ MT. Rata-rata biaya sewa lahan yang dikeluarkan petani per hektarnya adalah Rp 850.000,-.

Bunga modal juga termasuk kedalam biaya yang diperhitungkan dalam usahatani. Pada daerah penelitian, keseluruhan petani responden menggunakan modal sendiri dalam kegiatan usahataninya. Sehingga dalam usahatani harus ada perhitungan bunga modal yang dikeluarkan. Bunga modal tersebut didapat dengan cara perkalian antara biaya total sebelum masuk bunga modal dengan persentase suku bunga yang berlaku di daerah penelitian yaitu 14 persen per tahun. Dari hasil penelitian diketahui bahwa rata-rata besarnya biaya bunga modal yang dikeluarkan petani responden per hektar per musim tanamnya adalah sebesar Rp 2.801.949,40 per hektar per musim tanam.

\section{Penerimaan dan Pendapatan}

Penerimaan merupakan nilai yang diterima petani dari hasil penjualan usahataninya. Penerimaan disini dibedakan menjadi dua yaitu penerimaan tunai dam penerimaan yang diperhitungkan. Penerimaan tunai diperoleh dari banyaknya hasil produksi yang dijual dikalikan dengan harga jual petani. Sedangkan penerimaan yang diperhitungkan diperoleh dari banyaknya hasil produksi yang dikonsumsi baik untuk dikonsumsi pribadi maupun yang akan dijadikan bibit dikalikan dengan harga jual petani. Rata-rata produksi yang dijual responden per hektar untuk usahatani kentang merah adalah sebesar $9.450 \mathrm{~kg}$ dan produksi yang dikonsumsi sebesar $1.050 \mathrm{~kg}$. Harga jual kentang merah adalah $\mathrm{Rp} 7.500,-/$ $\mathrm{kg}$. Dengan demikian, rata-rata penerimaan tunai petani per hektarnya adalah sebesar Rp 70.947.949,50/ha dan rata-rata penerimaan yang diperhitungkan sebesar $\mathrm{Rp}$ 7.875.000.-/ ha.

Pendapatan atas biaya tunai usahatani merupakan selisih antara penerimaan tunai dengan biaya yang dibayarkan. Rata-rata pendapatan petani kentang merah per hektar adalah sebesar Rp 32.489.892,41/ ha.

Pendapatan atas biaya total usahatani merupakan selisih antara total penerimaan dengan biaya total. Rata-rata pendapatan atas biaya total (keuntungan) petani kentang merah per hektar adalah sebesar Rp 15.979.227,27/ha. Untuk lebih jelasnya pada Tabel 5 
disajikan data tentang besarnya penerimaan, pendapatan serta keuntungan rata-rata petani kentang merah di Kabupaten Solok.

Tabel 5 Rata-rata per hektar besarnya penerimaan, pendapatan dan keuntungan petani kentang merah MT Agustus - November 2017

\begin{tabular}{|c|c|c|}
\hline No & Keterangan & Jumlah (Rp) \\
\hline 1. & Penerimaan Tunai & 70947949.50 \\
\hline 2. & Penerimaan yang Diperhitungkan & 7875000.00 \\
\hline 3. & Total Penerimaan & 78822949.50 \\
\hline 4. & Biaya Dibayarkan (Biaya Tunai) & \\
\hline & - TKLK & 21418666.67 \\
\hline & - $\quad$ Bibit & 12000000.00 \\
\hline & - $\quad$ Pupuk & 4937500.00 \\
\hline & - $\quad$ Pestisida & 58000.00 \\
\hline & - $\quad$ Mulsa & 784818.27 \\
\hline & - $\quad$ PBB & 10000.00 \\
\hline & Total Biaya Dibayarkan & 38458057.09 \\
\hline 5. & Biaya Diperhitungkan & \\
\hline & - $\quad$ TKDK & 20610099.71 \\
\hline & - Peny. Peralatan & 123616.03 \\
\hline & - Sewa Lahan & 850000.00 \\
\hline & - Bunga Modal & 2801949.40 \\
\hline & Total Biaya Diperhitungkan & 24385665.13 \\
\hline 6. & Total Biaya & 62843722.23 \\
\hline 7. & Pendapatan atas biaya tunai & 32489892.41 \\
\hline 8. & Pendapatan atas biaya total & 15979227.27 \\
\hline 9. & Keuntungan per $\mathrm{Kg}$ & 1521.83 \\
\hline 10. & $\mathrm{R} / \mathrm{C}$ atas Biaya Tunai & 1.84 \\
\hline 11. & $\mathrm{R} / \mathrm{C}$ atas Biaya Total & 1.25 \\
\hline
\end{tabular}

Sumber : Data primer, 2017(diolah)

Pada Tabel 5 dapat dilihat bahwa keuntungan petani kentang merah per kilogramnya mencapai $\mathrm{Rp} 1.521,83 / \mathrm{kg}$. Untuk R/C atas biaya tunai sebesar 1,84 yang artinya setiap satu rupiah biaya tunai yang dikeluarkan maka akan memberikan penerimaan sebesar Rp 1,84 , sedangkan $\mathrm{R} / \mathrm{C}$ atas biaya total sebesar 1,25 yang artinya setiap satu rupiah biaya tunai yang dikeluarkan akan memberikan penerimaan sebesar Rp 1,25. Karena R/C ratio yang dihasilkan pada usahatani kentang merah besar dari satu, maka usahatani ini layak untuk dikembangkan.

\section{DAFTAR PUSTAKA}

Martin Let al. 1991. Agribusiness Competitiveness Across National Buoundaries. American Journal Agricultural Economics73: 1474-1475. Amerika Serikat (US)

Sejati K, Kustiari R, Rivai RS, Zakaria AK, Nurasa T. 2009. Kebijakan Intensif Usaha Tani Kedelai Untuk Mendorong Peningkatan Produksi dan Pendapatan Petani. Bogor (ID): Pusat Analisa Sosial Ekonomi dan Kebijakan Pertanian.

Soeharjo. 1991. Konsep dan Ruang Lingkup Agribisnis.Kumpulan Makalah Agribisnis. Bogor (ID): Institut Pertanian Bogor.

Soekartawi. 1995. Analisis Usahatani. Jakarta (ID): Universitas Indonesia (UI-Press). 
Soekartawi. 2002. Prinsip Dasar Ekonomi Pertanian. Jakarta (ID): Raja Grafindo Persada. Soekartawi. 2005. Agribisnis Teori dan Aplikasinya. Jakarta (ID): Raja Grafindo Persada.

Sukiyono K. 2005. Faktor penentu tingkat efisiensi teknik usaha tani cabai merah di Kecamatan Selupu Rejang, Kabupaten Rejang Lebong. Jurnal Agro Ekonomi 23(2):176-190.

Suratiyah K. 2006. Ilmu Usahatani. Jakarta (ID): Penebar Swadaya.

Yusri M. 2006. Analisis fungsi produksi usahatani padi sawah dan pengaruhnya terhadap produk domestik regional bruto (PDRB) untuk pengembangan wilayah di Kabupaten Deli Serdang [disertasi]. Medan (ID): Sekolah Pasca Sarjana Universitas Sumatera Utara. 